\title{
CONTEXTO DE APRENDIZAGEM DE PORTUGUÊS L2: COMUNIDADES DE PRÁTICA EM AMBIENTES MULTILINGUAIS/MULTICULTURAIS
}

\section{Context for Learning Portuguese as a Second Language: communities of practice in multilingual/multicultural environments}

\section{Ester Roos de MENEZES, Celin-UFPR ${ }^{1}$ Jovania Maria Perin SANTOS, Celin-UFPR ${ }^{2}$}

\begin{abstract}
RESUMO: O presente artigo visa descrever o contexto de aprendizagem de português como L2 no Centro de Línguas e Interculturalidade - Celin-UFPR ${ }^{3}$ e investigar a relação aluno-aluno na realização de tarefas colaborativas. Esta realidade de ensino envolve grupos multilinguais/multiculturais em situação de aprendizagem em imersão, ou seja, é a aprendizagem e uso de uma língua não-nativa (para o aprendiz) dentro de fronteiras territoriais onde ela é oficial. Para desenvolver este trabalho partimos do artigo "O outro no ensino de línguas" publicado por PAIVA (2011), em que a autora diz não ser a sala de aula um paraíso colaborativo. Aplicamos uma pesquisa qualitativa junto a alguns alunos do Celin e nos apoiamos em teorias de base vygotskiana e também na descrição de comunidades de prática realizada por WENGER (2008), entre outros autores, para analisar os dados coletados.
\end{abstract}

PALAVRAS-CHAVE: Ensino de PLE/PL2, Ensino em Imersão, Tarefas Colaborativas, Comunidades de Prática.

ABSTRACT: This article aims to describe the context of Portuguese instruction as an L2 at Center for Languages and Interculturality Celin-UFPR and to analyze the student-tostudent relationship while performing collaborative tasks. This teaching context involves multi-lingual/multi-cultural groups in a total immersion situation; that is, learning and using a non-native language (to the student) within the nation where it is the official language. This study will be based on the article "The other in language teaching" published by Paiva (2011) in which the author concludes that the classroom is not a collaborative paradise. We will also employ a survey given to some students at Celin; support from theories by community practices by Wenger (2008), among others, to analyze the collected data.

KEY WORDS: PLE/PL2 teaching, Teaching in immersion, Collaborative Tasks, Communities of Practice.

\footnotetext{
${ }^{1}$ Professora de Português como Língua Estrangeira no Celin - UFPR. Mestranda em Estudos Linguísticos na UFPR

${ }^{2}$ Professora de Português como Língua Estrangeira. Mestranda em Estudos Linguísticos na UFPR

${ }^{3}$ Celin-UFPR = É um espaço representativo para o desenvolvimento de práticas no campo de aquisição e aprendizado de língua estrangeira. Oferece cursos em 23 línguas, entre elas português para estrangeiros. É também um importante espaço de integração dos alunos de Letras da UFPR à prática docente.
} 


\section{INTRODUÇÃO}

Utilizaremos neste trabalho o termo L2 (segunda língua) no sentido genérico, assim definido por Rod Ellis (1985, p.5) sem a intenção de fazer um contraste com a aprendizagem de língua estrangeira (LE), a qual se refere à língua estudada em países em que não é oficial ou não tem função sociopolítica. No entanto, utilizamos no Celin-UFPR a abreviação PLE (Português como Língua Estrangeira) para denominar o curso de língua portuguesa ofertada a alunos estrangeiros. Esta abreviação facilita a compreensão por parte da comunidade de que se trata de ensino de língua portuguesa como língua não materna. Porém, no contexto de sala de aula podemos encontrar os alunos em diversas condições de aprendizagem de português. O ensino em imersão cria em sala de aula um contexto extraordinariamente diverso devido ao conhecimento de língua-alvo, interesses e necessidades pessoais, língua materna, conhecimento de outras línguas estrangeiras, hábitos de aprendizagem, letramentos, tempo de vivência no país, tempo de exposição à L2, etc. A lista é longa, e mesmo se tratando de ensino em imersão há aqueles que vivem e se relacionam quase que exclusivamente com compatriotas, estando assim, em imersão parcial. Por outro lado, há os que têm moradia fixa no país há algum tempo e utilizam o português no seu dia a dia para desempenhar atividades profissionais. Além disso, atualmente tem crescido a procura por aprender português por parte de falantes das chamadas línguas de imigração. São filhos de brasileiros, que nasceram e/ou cresceram no exterior e aprenderam a língua dos pais no âmbito familiar, tendo desenvolvido muito mais a oralidade do que a escrita.

O que nos preocupa, e é a razão principal deste artigo, é como se dá o processo de ensino/aprendizagem neste contexto dentro da perspectiva da aprendizagem colaborativa, ou seja, aprender desenvolvendo atividades junto com um colega. Em sala de aula há alunos que têm dificuldade em se relacionar com os outros e desenvolver atividades em conjunto. Há também alunos que apresentam estratégias de aprendizagem bastante tradicionais e têm dificuldade em aprender português dentro de uma nova abordagem.

Partimos da afirmação apresentada por PAIVA (2011), segundo a qual a sala de aula não é um paraíso colaborativo. Como muitas vezes nos deparamos com situações que corroboram essa ideia, pensamos em conhecer um pouco mais sobre essa realidade. Iremos nos direcionar para o aspecto da interação aluno-aluno e buscamos, através de pesquisa 
junto a estudantes do primeiro semestre de 2012, saber o que pensam sobre trabalhar em grupo ou em dupla nas aulas de português L2 em contexto multilingual/multicultural.

\section{TAREFAS COLABORATIVAS - BREVE HISTÓRICO E CONCEITOS}

No centro deste estudo está uma reflexão sobre a prática de tarefas colaborativas em grupos de aprendizes de português como língua estrangeira (PLE). Para isso, iremos inicialmente apresentar um breve histórico sobre a abordagem por tarefas. Consideramos que as tarefas colaborativas fazem parte dessa abordagem e se caracterizam por serem realizadas com a interação entre dois ou mais colegas, seja através da negociação de significados ou da colaboração entre os pares. Alguns exemplos de tarefas colaborativas: em grupo ou dupla, definir as 3 melhores maneiras de economizar água em casa; reconstruir uma estória contada em áudio ou pelo professor, (XAVIER 2011, p.152).

O ensino organizado com base na abordagem por tarefas surgiu como alternativa para organização de um programa de curso, pois antes desta abordagem, conforme explica a pesquisadora Sheila Estaire (2009, p.11) “o programa de um curso de línguas estrangeiras se especificava a partir de uma lista de conteúdos linguísticos: estruturas gramaticais em um enfoque estrutural (...)". Mesmo com a abordagem comunicativa "o programa de curso continuou sendo regulado pela língua e assumindo que a língua se aprende de forma acumulativa, em uma sequência linear" (ESTAIRE 2009, p.11). A partir de 1980, segundo Estaire (2009, p.11), a luz da experiência em sala de aula com o enfoque comunicativo, percebeu-se que havia a necessidade de organizar o ensino de forma diferente. A abordagem por tarefas se apresentou como uma alternativa por se ajustar melhor aos processos psicolinguísticos implicados na aquisição da língua.

A abordagem por tarefas surge, então, no ensino de línguas como um aprimoramento da abordagem comunicativa e em meio aos estudos e a propostas de ensino pós-estruturais. Frequentemente, refere-se ao estruturalismo como sendo uma metodologia que privilegia o ensino de regras e a realização de exercícios mecânicos a partir de uma frase modelo. Vários materiais didáticos foram/são concebidos dentro dessa linha teórica. Já a abordagem comunicativa teve início nos anos 1970 e previa uma reflexão sobre a língua como instrumento de comunicação. A partir daí, surgiram diversos métodos e 
abordagens de ensino de línguas voltados a práticas comunicativas ao invés de repetições mecânicas.

No final dos anos 1980, o linguista David Nunan publicou uma edição voltada à descrição e orientação quanto ao ensino de línguas baseado em tarefas. Nunan (1989, p.10) cita o seguinte conceito de tarefa: "uma parte do trabalho realizado em sala de aula que envolve os alunos na compreensão, manipulação, produção ou interação na língua-alvo enquanto que a atenção está principalmente focalizada no significado em vez da forma".

O conceito citado por Nunan (1989, p.10) reforça a passagem entre um paradigma linguístico-estrutural para o comunicativo, mas não cita o resultado ou a realização da tarefa. Esse é bastante abrangente e com isso faz com que muitas atividades sejam consideradas tarefas segundo esta perspectiva.

Para Ellis (2003, p. 16) tarefa é:

Um plano de trabalho que requer que os alunos processem a linguagem pragmaticamente, a fim de alcançar um resultado que pode ser avaliado em termos de saber se o conteúdo foi transmitido. Com este fim, a tarefa exige do aprendiz atenção primária ao significado e ao uso de seus próprios recursos linguísticos, embora o design de uma tarefa possa prever escolhas linguísticas particulares. Uma tarefa é entendida como o resultado da língua em uso que tem uma semelhança, direta ou indireta, com a forma como a linguagem é usada no mundo real. A tarefa pode envolver habilidade produtiva ou receptiva, e oral ou escrita, e também processos cognitivos diversos. ${ }^{4}$

O linguísta Rod Ellis cita um conceito bem elaborado que evidencia o processo de realização das tarefas, o resultado (outcome) e a avaliação do conteúdo. Seguindo a mesma linha Xavier (2011, p. 161) cita o ensino com base em tarefas como instrumentos pedagógicos “que estabelecem propósito comunicativo para o insumo verbal e não verbal a ser compreendido ou produzido na LE, visando um resultado comunicativo a ser alcançado.

De acordo com Barbirato (2005, p. 71) a preocupação em definir o termo tarefa foi seriamente abordada dentro do Projeto Celpe-Bras. Como elaboradora deste projeto Scaramucci (2001, p. 80) define tarefa

\footnotetext{
${ }^{4}$ Original em inglês - nossa tradução

A task is workplan that requires learners to process language pragmatically in order to achieve an outcome that can be evaluated in terms of whether the correct or appropriae propositional content has been conveyed. To this end, it requires them to give primary attention to meaning and to make use of their own linguistic resources, although the design of the task may predispose them to choose particular forms. A task is intended to result in language use that bears a resemblance, direct or indirect, to the way language is used in the real world. Like other language activities, task can engage productive or receptive, and oral or written skills, and also various cognitie processes.
} 
como um termo usado em Linguística Aplicada para se referir a uma atividade de ensino ou de avaliação diferente daquela usada nas abordagens tradicionais. Ela tem um propósito comunicativo, especificando para a linguagem usos que se assemelham àqueles que se têm na vida real. Ela permite a apresentação de conteúdos "autênticos", ou seja, extraídos de jornais, revistas e livros, não necessariamente elaborados para o ensino de línguas, e sempre dentro de um contexto maior de comunicação, para que o candidato possa ajustar o registro de linguagem às necessidades da situação. São exemplos de tarefas: assistir a um vídeo e ser capaz de se posicionar com relação ao assunto apresentado, escrever uma carta solicitando informações, deixar um recado em uma secretária eletrônica, etc.

Neste conceito Scaramucci define a tarefa como atividade de ensino e de avaliação, inserida na abordagem comunicativa, que privilegia os usos da linguagem em situações da vida real.

As definições descritas apontam para a existência das seguintes condições na constituição de uma tarefa (citadas por Skehan 1998, p.5):

1. Há primazia no sentido

2. O trabalho tem como objetivo a resolução de um problema

3. Os resultados da atividade são avaliados

4. Há uma relação com o mundo real

Há conceitos que parecem conter as condições acima, mas agregam outros valores. É o caso do conceito citado por Schlatter, Garcez e Scaramucci (2004, p. 360) que inovam ao considerar as tarefas como interações situadas. Esse conceito tem como base a noção de interação e, além disso, a visão de que "a atividade em que se envolvem os aprendizes poderá variar de acordo com os participantes, circunstâncias e investimento na interação a partir de diferentes objetivos, background cultural, necessidades e motivação em iniciar reparos para resolver um problema de compreensão." Segundo os autores a produção de uma tarefa depende dos objetivos dos participantes, e não apenas dos objetivos e instruções intencionados pelas tarefas.

Dentro dessa perspectiva Andrighetti considera as "tarefas como oportunidades de convidar o aluno a participar em situações de uso da linguagem com propósitos definidos e em contextos específicos." Assim, as tarefas são vistas como um convite para agir e se engajar em diferentes atividades. Aqui percebe-se uma valorização da tarefa enquanto atividade de interação e especialmente sinaliza para a especificidade de atuação do aluno enquanto elemento central desse processo. Esse conceito se embasa no pressuposto de que 
aprender uma língua é aprender a usá-la para (inter)agir com diferentes propósitos e interlocutores.

Dentro da perspectiva do ensino com base em tarefas e da abordagem orientada para a ação o texto (falado ou escrito) passa a constituir o eixo de uma atividade de língua, conforme citado no QECR (2001, p.10). Estando o texto no centro deste processo ou direcionando-o está também a concepção de língua como discurso. Segundo a pesquisadora Clarissa Jordão (2006, p.7):

conceber língua como discurso é perceber a língua como ideológica, perpassada por relações de poder que ela mesma constrói; é perceber as marcas de determinações culturais nos textos que produzimos; é perceber os gêneros discursivos como mecanismos de estabelecimento de sentidos possíveis.

Pensar o ensino e aprendizagem de línguas concebido como discurso significa voltar-se para a reflexão, interpretação e construção de significados no mundo em que vivemos. Sendo assim, na concepção da língua como um código, o foco na forma e sintaxe muda de direcionamento. A forma - regras gramaticais - passa a ser vista como uma ferramenta para que se possa atingir os objetivos propostos voltados a comunicação e ao agir social.

Assim, as tarefas propostas em sala de aula envolvem a produção de textos - orais ou escritos - considerando a complexidade da sua produção e se centram no significado e na mensagem.

Não acreditamos que a abordagem em tarefas deixe de lado o insumo gramatical ou o foco na forma. Muitas críticas já foram feitas a essa abordagem afirmando que peca no quesito gramatical ou sistematização gramatical. Pensamos ser de bom senso que o professor retome estruturas gramaticais ou que dê espaço para tirar as dúvidas dos alunos quanto a tópicos gramaticais durante a realização das tarefas. Porém, os danos para a aprendizagem serão muito maiores se o professor (ou o material) direcionar/privilegiar a aula para a prática gramatical, desconsiderando adequações discursivas e socioculturais. Através da abordagem por tarefas inevitavelmente os aprendizes terão que usar a língua e com ela sua estrutura sintática, lexical, semântica, fonética, etc. estará presente. Durante esse processo o professor terá muitas oportunidades para explorar dúvidas voltadas à língua (código). O resultado do trabalho realizado durante a execução de uma tarefa realmente irá revelar a capacidade linguística dos alunos. Aqui, entendemos a capacidade 
linguística como a capacidade de comunicar-se através da língua-alvo em situações reais de comunicação.

\section{APRENDER UMA LÍNGUA EM AMBIENTE MULTILINGUAL/MULTICULTURAL - DESCRIÇÃO DO CONTEXTO}

O homem é constituído por suas experiências e por suas influências culturais e está continuamente exposto a novas experiências, as quais irão estabelecer novos comportamentos causando modificações pequenas ou grandes. Assim, o homem é um ser culturalmente constituído através do meio social em que vive. Neste sentido, pensa-se a cultura, como explica Oliveira (1997, p.38) com base em Vygotsky, não como algo pronto, um sistema estático ao qual o indivíduo se submete, mas como algo em constante movimento de recriação e reinterpretação de informações, conceitos e significados. A perspectiva vygotskiana (2007) preconiza que a interação social é de importância vital no desenvolvimento cognitivo por ser considerada mediadora do processo de aprendizagem.

Considerando a condição de aprendizagem de línguas a noção de interação é fundamental para o desenvolvimento da aprendizagem, sobretudo quando baseada no processo de aprendizagem colaborativa. Este processo apresenta "duas noções básicas: o compartilhamento e o empréstimo de conhecimento entre os envolvidos" (HYLAND, 2004). Nesse sentido a ideia de compartilhamento, diz que alunos que aprendem juntos aprendem mais do que separadamente. A noção de empréstimo refere-se ao fato de que alunos que aprendem com um par mais competente entendem melhor as tarefas de aprendizado e, por isso, este aprendizado é mais eficiente.

De acordo com Douglas Brown (1994), atitudes positivas podem ajudar os aprendizes de uma segunda língua a conseguirem maior proficiência, ao mesmo tempo em que atitudes negativas levam à perda de motivação dos aprendizes. A consequência seria diminuição da quantidade de input e prejuízos na interação. Como resultado haveria fracasso na obtenção da proficiência desejada.

Observamos nestes anos de prática de ensino de PLE que em alguns grupos há maior interesse em desenvolver atividades, principalmente orais, com todo o grupo ao invés de trabalhar com um ou dois colegas apenas. Esta preferência pode ter várias razões, entre elas: 
- Executar atividades não apenas com um ou dois colegas, mas em com todo o grupo é mais cômodo porque não é necessário participar o tempo todo. A opinião dos colegas mais competentes e, a mediação do professor, irá facilitar o desenvolvimento do trabalho;

- Compreender alguns colegas é mais difícil devido às interferências de língua materna, a qual não é conhecida pelo colega. O esforço para a compreensão do outro em alguns casos pode ser muito grande, o que estimularia a negociação de significado, mas tornaria a atividade mais cansativa e menos atraente;

- Trabalhar com um par menos competente, nem sempre é interessante para um aluno mais competente.

Para Vera Lúcia Menezes de Oliveira e Paiva (2008), em artigo chamado "O outro na aprendizagem de línguas", embora a teoria sociocultural (Lantolf, 2000) venha ganhando espaço nos estudos sobre aquisição e as ideias de Vygotsky sobre o desenvolvimento de conceitos pelas crianças tenham sido amplamente aplicadas ao universo adulto, é relevante rever essas aplicações, "levando-se em consideração não apenas as diferenças entre adultos e crianças, mas também a natureza do fenômeno da aquisição de língua estrangeira" (PAIVA 2008, p. 01).

O conceito de zona do desenvolvimento proximal (ZDP) foi defendido por Vygotsky durante os intensos debates sobre educação na década de 1930 (na Europa). Seus estudos tiveram como base a observação dos processos de aprendizagem $\mathrm{e}$ desenvolvimento mental de crianças. No livro "A formação social da mente" é apresentado o conceito de ZDP segundo Vygotsky como sendo: "a distância entre o nível de desenvolvimento real (da criança) determinado pela resolução de problemas independentemente e o nível de desenvolvimento potencial determinado pela resolução de problemas sob orientação de adultos ou em colaboração com companheiros mais capacitados.” (2007, p. 97). Seria, então, este conceito totalmente aplicável para o processo de aprendizagem de língua estrangeira e para adultos? Seria como dois triângulos idênticos colocados um sobre o outro de modo que só se pudesse ver um?

O processo de aquisição de língua materna (LM) e da aprendizagem de língua estrangeira por adultos passa por caminhos nem sempre idênticos. Quanto à aprendizagem de LE por adultos percebemos que a cultura pessoal, desenvolvida historicamente, pode apresentar barreiras ou resistências, ou mesmo ser elemento de constante comparação ao 
aprender uma nova língua. Nesse sentido observamos que os alunos que estão mais abertos ao "novo" e ao "outro", absorvendo/incorporando o que as relações interpessoais lhes oferecem, apresentam nível de aprendizagem muito mais alto.

Para Paiva (2008), a aplicação do conceito de ZDP ao universo da aprendizagem colaborativa entre adolescentes ou entre adultos é pouco adequada, especialmente no âmbito da aquisição de línguas estrangeiras. Conforme explica a autora,

a transposição desse conceito implica romantizar a participação do par mais competente, e minimizar o papel dos artefatos culturais que podem ser mediadores eficazes na aprendizagem autônoma. Além disso, nos leva a crer, erroneamente, que a aquisição acontece em um ambiente formal, dividido entre alunos mais competentes e menos competentes (PAIVA 2008, p. 3).

Paiva (2008) não anula a importância do outro na aprendizagem. Ela considera que o outro pode funcionar como um andaime, ou seja, potencializar as habilidades do colega e colocar o processo de aquisição em movimento. Por outro lado, o outro na aprendizagem "nos faz ver o contexto social não apenas como ambiente de cooperação, mas, também, como arena de conflitos e de frustrações” (PAIVA 2008, p. 3). A autora discute "o processo de aquisição como um fenômeno complexo, não-linear, dinâmico e imprevisível" e apresenta evidências empíricas coletadas em pesquisa dizendo que "o par mais competente nem sempre se dispõe a ajudar ou, ainda, que seu desempenho linguístico pode funcionar como elemento inibidor, transformando-se em barreira psicológica para o colega" (PAIVA 2008, p.3). Dessa forma, não haverá a criação de uma ZDP, não havendo colaboração entre os pares.

\section{ENSINO DE L2 EM AMBIENTE FORMAL - UMA COMUNIDADE DE PRÁTICA}

Considerando o contexto de aprendizagem, quem é o outro (interlocutor) com quem nossos alunos têm contato em sala de aula? Pode ser o professor, pessoas da mesma nacionalidade, pessoas de culturas e falantes de línguas estrangeiras conhecidas ou até mesmo de cultura e língua completamente desconhecidas pelo aluno. Ao chegar no Celin, os alunos fazem teste de nivelamento e com isso chega-se a níveis de proficiência relativamente próximos. Os alunos hispanófolos estudam em grupos separados, mas nestes 
grupos também participam normalmente outros latinos como franceses ou italianos e muitas vezes alunos não latinos, mas que falam espanhol como LE ou L2. Nos níveis intermediários, é comum termos no mesmo grupo hispanos e asiáticos. Nesses grupos se estabelece, via de regra, um ambiente de integração no início do curso. Acreditamos que o fato de serem todos estrangeiros e precisarem estabelecer laços sociais são elementos que fortalecem essa integração.

Os grupos de aprendizes de línguas formam o que Etienne Wenger (2008) chama de comunidades de prática e desenvolvem uma identidade. Seguiremos com um resumo de conceitos apresentados por Wenger (2008).

As comunidades de prática são grupos de pessoas que têm em comum interesses ou objetivos. A identidade segundo Wenger (2008:151) é uma sobreposição de eventos de participação e reificação pelo qual nossa experiência e sua interpretação social formam-se mutuamente. $\mathrm{O}$ autor afirma que a identidade serve como um eixo entre o social e o individual, cujo foco deve estar no seu processo de constituição mútua. A reificação ${ }^{5}$ é definida por ele como o processo de dar forma à nossa experiência, produzindo objetos que congelam essa experiência em "coisificação".

$\mathrm{Na}$ interação entre participação e reificação é que emerge a identidade na prática. $\mathrm{Na}$ sucessão de formas de participação nossa identidade forma trajetórias tanto internas a uma comunidade de prática como também entre diferentes comunidades. Essas trajetórias não percorrem caminhos pré-fixados nem podem ser previstas ou planejadas. Antes consistem de um movimento contínuo, com dinâmica própria; são temporalmente coerentes e ligam passado, presente e futuro.

Wenger (2008, p. 154) classifica diferentes possibilidades de trajetórias dentro das comunidades de prática, como:

- Trajetórias periféricas ${ }^{6}$ : por opção ou por necessidade, algumas trajetórias nunca levam à participação plena.

\footnotetext{
5 Nas palavras de Wenger: "I will use the concept of reification very generally to refer to the process of giving form to our experience by producing objects that congeal this experience into "thingness"”. (2008, p. 57)

6 - Peripheral trajectories: By choice or by necessity, some trajectories never lead to full participation.

- Inbound trajectories: Newcomers are joining the community with the prospect of becoming full participation.

- Insider trajectories: The formation of an identity does not end with full membership. The evolution of the practice continues - new events, new demands, new inventions, and new generations all create occasions for renegotiating one's identity.
} 
- Trajetórias de entrada: Os novatos são convidados a comunidade com a perspectiva de passarem a participação plena.

- Trajetórias internas: A formação de uma identidade não termina com a adesão plena. A evolução da prática continua - novos eventos, novas demandas, novas invenções, e as novas gerações tudo cria ocasiões para renegociar identidade de cada um.

- Trajetórias de fronteira: Algumas trajetórias encontram o seu valor quando atinguem as fronteiras e ligam as comunidades de prática.

- Trajetórias de saída: algumas trajetórias levam para fora de uma comunidade, como quando as crianças crescem.

O fato de pertencer a uma comunidade de prática nos dá a sensação de estarmos em um território familiar, no qual nos sentimos competentes e somos reconhecidos como tal. Essa zona faz com que nos sintamos envolvidos com as atividades porque compreendemos as operações, sabemos por que e como os processos se dão, compartilhamos o discurso e os recursos utilizados pelos membros nas atividades.

Ao entrar em contato com novas práticas, no entanto, nos aventuramos em um território desconhecido e o resultado é um sentimento de falta de competência. A transposição de fronteiras pode se manifestar em três áreas da identidade: no comprometimento mútuo, no engajamento e no compartilhamento do repertório. Quando nos encontramos em territórios desconhecidos, não sabemos exatamente como nos envolver com os outros membros e também não entendemos exatamente as especificidades compartilhadas pelos membros efetivos daquela comunidade. Aí entra a não-participação, uma das possibilidades que utilizamos para nos confrontar com o novo e desconhecido. $\mathrm{O}$ autor afirma que a não-participação é uma parte inevitável de se viver em um cenário de práticas, pois, uma vez que nossas práticas incluem elementos de comunidades das quais não participamos efetivamente, vivemos em um entrelaçado de comunidades e constantemente estamos cruzando fronteiras e vislumbrando outras realidades e significados. Embora nem tudo o que encontramos nos seja significativo, ou seja, diretamente influenciado por nossas opiniões ou decisões, ainda assim podem contribuir para nossas experiências de identidade e de reificação.

- Boundary trajectories: Some trajectories find their value in spanning boundaries and linking communities of practice.

- Outbound trajectories: Some trajectories lead out of a community, as when children grow up. 
Embora a palavra comunidade seja usualmente relacionada a uma ideia positiva, o autor (2008, p. 77) destaca que paz, felicidade e harmonia não são necessariamente propriedades de uma comunidade de prática. Certamente há muitas divergências, tensões e conflitos neste contexto. O engajamento em uma comunidade de prática não depende só da nossa competência, mas também da dos outros. Wenger descreve as relações mútuas na vida real como misturas complexas de poder e dependência, prazer e dor, (...) autoridade e coleguialidade, resistência e complacência, (...) ternura e repugnância, diversão e tédio, confiança e desconfiança, amizade e ódio. Comunidades de prática têm tudo isso (WENGER, 2008, p. 77).

Conforme descreve Wenger, não podemos esperar que as comunidades de prática sejam espaços harmoniosos. Haverá sempre diversidade e não podemos considerar que a aprendizagem só ocorra em comunidades harmoniosas. Aprende-se também em situações adversas ou durante discussões, por exemplo.

Em ambiente de sala de aula parece-nos claro que quanto mais engajado for o grupo e maior a colaboração ou cooperação mais propício estará à aprendizagem. Porém, isso não significa dizer que a aprendizagem só ocorra em ambiente de colaboração.

\section{ANÁLISE DOS DADOS}

Para a análise dos dados, vale considerar que as professoras dos três grupos pesquisados propuseram tarefas colaborativas durante os cursos e que duas delas têm mais de 10 anos de experiência no ensino de PLE e vêm pesquisando a abordagem por tarefas no ensino de LE.

Aplicamos um questionário a alunos de dois níveis: intermediário 1 (curso intensivo, janeiro/fevereiro 2012) e pré-intermediário (curso extensivo, primeiro semestre 2012). Sendo dois grupos de alunos do nível pré-intermediário. No total obtivemos 24 questionários respondidos, 4 foram enviados por e-mail e os outros respondidos em sala. Os alunos serão identificados por ordem de recebimento dos questionários. Nosso objetivo foi fazer uma pesquisa exploratória, portanto qualitativa, voltada à descrição e interpretação das informações coletadas.

Procuramos digitar as respostas conforme fornecidas pelos alunos, no entanto, em alguns casos fizemos pequenas correções ortográficas. Observamos ainda que alguns 
alunos talvez não tenham entendido plenamente certas perguntas. Os primeiros questionários (alunos 1 a 5) foram colhidos de alunos do nível intermediário 1 e respondidos em casa. Já os questionários restantes foram respondidos na sala de aula por alunos de nível pré-intermediário. Observamos que estes últimos não se aprofundaram nas respostas. Acreditamos que tenha sido por possíveis limitações de ordem linguística aliadas ao curto espaço de tempo disponível para redigir as respostas.

Procuramos durante a elaboração das questões ser bastante objetivas pois a maioria se tratava de alunos de nível pré-intermediário.

Os alunos entrevistados têm a seguinte proveniência: 1 da Rússia; 1 do Togo; (francófono); 1 de Benin (francófono); 1 do Vietnã; 1 da Noruega; 1 do México; 1 da Argentina; 2 dos Estados Unidos; 2 do Japão; 2 da França; 4 da República Democrática do Congo (francófonos) e 7 da Coreia do Sul.

\section{ANÁLISE DAS RESPOSTAS ÀS PERGUNTAS 2 E 3}

As questões 2 e 3 versavam sobre o trabalho com um colega ser agradável e produtivo. Na pesquisa que realizamos, observamos que a maioria dos depoimentos converge para a ideia de que é agradável e proveitoso trabalhar colaborativamente em sala de aula. Dos 24 alunos entrevistados, 17 responderam "sim" às perguntas 2 e 3 . Um aluno, porém, disse só trabalhar com um colega se tiver que fazer isso. Segundo esse aluno, sem a correção do professor não tem nenhum sentido trabalhar em grupo. Outro aluno não respondeu às perguntas 2 e 3; nas outras respostas este aluno demonstrou neutralidade. Ainda outro aluno disse achar agradável fazer atividades com os colegas, mas nem sempre as considera produtivas, depende da pessoa/colega. Outro aluno ainda disse não gostar de fazer atividades com os outros, mas explica que não teve problemas durante o curso, enquanto outro aluno disse não ser uma atividade agradável trabalhar com os colegas, mas que considera positivo o aspecto de entender a cultura do outro. Outro aluno considerou ser uma atividade produtiva, mas afirmou que às vezes é agradável e às vezes não é; ainda outro aluno afirmou ser agradável, mas não produtivo.

Ressaltamos a declaração de um dos alunos que considerou essencial a presença do professor para corrigi-lo: 
Eu gosto de atividades quando um professor primeiro dá para nós lista de vocabulário e frases sobre um assunto e 2 alunos ou grupo tem que discutem sobre este assunto utilizando essas palavras e frases. No tempo de discussão o professor ouve e corrige. Sem a correção do professor não tem nenhum senso de trabalhar em grupo.

A sala de aula de curso de língua em imersão é vista por muitos alunos estrangeiros, como um lugar para se tirar dúvidas, aprender gramática e vocabulário, sobretudo nos níveis intermediários. De acordo com contribuições de um de nosso alunos:

Só se eu tiver que. Acho que todos nós esperamos da escola mais do que falar (trabalhar) com outro estudante. Seria ótimo se tivéssemos mais gramática e aprender mais vocabulário. Eu acho que a gramática é fundamento, vocabulário é algo como paredes da casa - escola precisa ajudar a construí-los. É telhado da casa - prática falar com as pessoas - o aluno pode construir por si mesmo, praticando em seu tempo livre.

Acreditamos que a opinião desse aluno vai de encontro com uma visão tradicional de ensino, na qual o enfoque linguístico é prioritário. Tal enfoque ganha força no ensino em imersão, por haver oportunidades de comunicação em língua alvo fora da sala de aula.

\section{ANÁLISE DAS RESPOSTAS ÀS PERGUNTAS 5 E 6 :}

As questões 5 e 6 versavam sobre o sentimento em relação ao desenvolvimento de atividade em sala com um colega cujo nível linguístico era superior ou inferior ao dele próprio. De modo geral, trabalhar com um colega com nível acima foi declarado pelos participantes da enquete como positivo principalmente por ser um desafio ou algo motivador. Também foi citado por vários alunos o fato de que um colega mais competente pode lhe ensinar ou lhe ajudar, que ele pode aprender com o outro. Apenas dois alunos afirmaram não ser positivo trabalhar com um colega com nível linguístico superior ao seu.

O comentário de um aluno nos chamou a atenção pelo fato de que este aluno julgou ser difícil trabalhar colaborativamente no início, mas ele se habituou a essa prática no decorrer do curso:

No início parece sempre difícil de trabalhar com uma pessoa que tem muitas diferenças, sobretudo a diferença das línguas. Imagine que você esteja em frente duma pessoa com quem você deve trabalhar junto, mas numa língua que vocês dois não falam bem; cada um terá medo de falar errado. Mas com tempo tudo fica fácil, porque já se acostumaram de falar errado e de ser corrigido pela professora. E nesse momento essa diferença ajudará porque será obrigado de falar a língua que vocês estão aprendendo. 
Sobre trabalhar com um colega com nível abaixo, obtivemos o maior número de respostas diferentes e também de não respostas. Podemos inferir que a omissão em dar resposta é um indicativo de que se tratava de uma resposta mais difícil de ser elaborada ou ainda ser indicativa do descontentamento ou da pouca disposição em trabalhar colaborativamente com um colega de nível mais baixo. Essa ideia confirma a tese de Paiva (2008) de que o outro nem sempre contribui para criar a ZDP, porém estes alunos não demonstraram se negar a trabalhar colaborativamente. Ao todo, cinco alunos não responderam a pergunta de número 06.

Alguns estudantes responderam que ajudando o outro também podem aprender, como verificado na seguinte declaração: “Acho que também me ajudaria, porque então eu preciso repetir o que já aprendi quando ajudo o outro estudante.” Esta declaração segue a linha de outra: "Também pode ser um pouco desconfortável, mas é bom porque assim você tenta a ajudar a seu colega para que entenda melhor, e assim você tem que procurar o melhor jeito de falar.”. Já quatro alunos deram declarações satisfeitas em relação a poder ajudar o colega.

Algumas respostas nos chamaram a atenção por serem diferentes de todas as outras. Um aluno, por exemplo, disse se sentir envergonhado ao trabalhar com um colega que sabe menos do que ele. Por outro lado, um aluno disse se sentir mais confortável, e outro afirmou se sentir feliz, pois: "Eu me senti feliz, fluente como se eu estou (estivesse) melhorando."

Nesta questão obtivemos mais respostas negativas, ou seja, alunos demonstrando insatisfação, mesmo que algumas respostas não tenham sido muito explicativas, uma vez que um aluno escreveu "Nada", e outro escreveu "Ruim". Outros dois insatisfeitos declararam: "Acho que é ruim. Não posso me desenvolver." e "Era difícil também porque eles gastavam muito tempo desnecessário. Mas, era bom para aprender as coisas básicas."

Algumas respostas não foram claras ou coerentes com a pergunta, demonstrando incompreensão por parte do entrevistado. Ainda dois alunos não responderam as questões 5 e 6 , e outros dois alunos pareceram neutros ou não ter entendido a pergunta. 


\section{CONCLUSÃO}

Foram as respostas das questões 5 e 6 que mais nos intrigaram e nos ajudaram a perceber a complexidade do trabalho colaborativo em sala de aula. Não pretendemos com este artigo questionar ou corroborar teses aqui apresentadas, mas levantar questões importantes sobre o tema apresentado e procurar conhecer mais sobre a abordagem por tarefas e o trabalho colaborativo entre nossas aulas.

Percebemos que nossos grupos de aprendizes de português formam comunidades de práticas conforme a descrição de Wenger (anteriormente apresentada). Pudemos observar que, por exemplo, ao entrar em contato com novas práticas alguns alunos se aventuram em território desconhecido e têm um sentimento de falta de competência como os alunos que falavam da dificuldade que tiveram no início do curso. Há os que se sentiam em uma trajetória periférica quando disseram que não gostavam de trabalhar com o outro.

O que nos parece claro é que interligar os alunos é uma tarefa extremamente relevante, pois permite ampliar fronteiras de prática e com isso ampliar a possibilidade de crescimento/engajamento. $\mathrm{O}$ depoimento de um dos alunos reforça a ideia de que quanto maior a interação, maior a atitude de colaboração e a pré-disposição para a aprendizagem. Foi o que demonstrou um aluno ao dizer que estava muito satisfeito com o curso, com a abordagem utilizada pela professora e com a escola. Embora ele apresentasse nível de competência linguística acima de todos os outros, não havia alunos suficientes para abrir um grupo de nível avançado e o horário daquela turma era o único no qual ele poderia estudar. Este aluno se caracterizava por ser estudioso, colaborar com as atividades propostas pelo professor e interagir com todos os colegas, mesmo tendo que desenvolver tarefas com alunos com dificuldades, ele achou essa experiência interessante. Ao responder o questionário demonstrou opinião positiva a tudo o que foi realizado em sala de aula.

Depreendemos de todas as respostas dadas que a questão é como chegar a um ambiente cooperativo em sala de sala. Acreditamos depender de todos: do professor, dos alunos, da instituição e do material didático. Um fino ajuste é necessário para que tudo flua bem, mesmo porque em sala de aula existem alunos com interesses diversos, também há os interesses e potencial dos professores e da instituição e conciliar todos nem sempre é possível. 
O papel do professor dentro de uma comunidade de prática de alunos de LE e especialmente de PL2 pautado no trabalho colaborativo é criar/propiciar um espaço de engajamento. Logo no início do curso deve-se informar sobre a importância da colaboração e da troca de experiências; falar sobre a importância em aprender com o outro e do quanto podemos ganhar em riqueza cultural conhecendo pessoas de diferentes lugares e de diferentes opiniões.

Pensar o ensino de línguas com base em tarefas colaborativas requer do professor atenta observação e a consideração de diversos fatores constitutivos dos grupos de trabalho ou das comunidades de prática. Nem sempre estaremos diante de pares ideais onde um contribuiu com o outro, mas assim são as comunidades de prática. As diferenças entre alunos de LE, como citado na introdução, são ainda maiores para alunos em imersão. Essas diferenças devem ser levadas em conta no momento da elaboração das tarefas a serem solicitadas aos alunos, bem como durante a sua aplicação. Toda essa complexidade aliada à carência de material didático de PLE de qualidade faz com que muitas vezes o professor siga muito mais a abordagem didática com base linguística apenas ou se restrinja a atividades comunicativas pouco efetivas.

\section{REFERÊNCIAS}

ANDRIGHETTI, Graziela Hoerbe. A elaboração de tarefas de compreensão oral para o ensino de português como língua adicional em níveis iniciais. Dissertação de Mestrado. UFRGS: Porto Alegre, 2009.

BAKHTIN, Mikhail. Marxismo e filosofia da linguagem: problemas fundamentais do método sociológico na ciência da linguagem. Tradução do francês por Michel Lahuad e Yara Frateschi Vieira. São Paulo: Hucitec, (1979).

BARBIRATO, Rita de Cássia. A tarefa como ambiente para aprender LE. Dissertação de Mestrado. Unicamp : Campinas, 1999.

BRASIL. Certificado de Proficiência em Língua Portuguesa para Estrangeiros: Manual do Aplicador. Secretaria de Educação Superior (SESu). Brasília: MEC, 1998a. Disponível em: http://portal.mec.gov.br/sesu/arquivos/pdf/CelpeBras/manualcandidato2006.pdf. Acesso em 11/02/2012.

BROWN, H. Douglas. Teaching by Principles: An Interactive Approach to Language Pedagogy. New York: Pearson Education, 2nd ed., 2001. 
ELLIS, Rod. Task-based Language Learning and Teaching. Oxford, Oxford University Press, 2003

ESTAIRE, Sheila. El aprendizage de línguas mediante tareas: de la programação al aula. - Madrid : Editorial Edinumen, 2009.

HYLAND, Ken. Genre and Second Language Writing. Ann Arbor: University of Michigan Press, 2004.

JORDÃO, Clarissa Menezes. O Ensino de Línguas Estrangeiras: de código a discurso. IN: VAZ BONI, Valéria. Tendências Contemporâneas no Ensino de Línguas. União da Vitória: Kaygangue, 2006.

NUNAN, David. Designing Tasks for the Communicative Classrooms. Cambridge: Cambridge University Press, 1989.

OLIVEIRA, Martha Kohl de. Vygotsky Aprendizagem e desenvolvimento: um processo sócio-histórico / Martha Kohl de Oliveira. - São Paulo : Scipione, 1997. - (Pensamento e ação no magistério)

PAIVA, Vera Lúcia de Menezes e. Interação e aprendizagem em ambiente virtual / Vera Lúcia Menezes (Organizadora). - 2ª ad. - Belo Horizonte: Editora UFMG, 2010. 405 p. : Il. - (Invenção)

O outro na aprendizagem de línguas / Vera Menezes (UFMG/CNPq/FAPEMIG). 2008. Disponível em http://www.veramenezes.com/outro.pdf. Acesso em 18/02/2012.

Quadro Europeu Comum de Referência para as Línguas - Aprendizagem, ensino, avaliação. Conselho da Europa, $1^{\mathrm{a}}$ ed - Portugal : ASA Editores II, S.A., 2001.

SCARAMUCCI, M. V.R. O projeto CELPE-Bras no âmbito do Mercosul: contribuições para uma definição de proficiência comunicativa. In: ALMEIDA FILHO, José Carlos Paes (org.) Português para estrangeiros interface com o espanhol. Campinas, SP : Pontes, $2^{\text {a }}$ edição, 2001.

SCHLATTER, Margarete; GARCEZ, Pedro de M.; SCARAMUCCI, Matilde V. R. O papel da interação na pesquisa sobre aquisição e uso de língua estrangeira: implicações para o ensino e para a avaliação. Letras de Hoje, 39 (3): 345-378.

SKAHAN, Peter. A Cognitive Approach to Language Learning. Oxford: Oxford University Press, 1998.

VIGOTSKY, Lev Semenovich, A formação social da mente: o desenvolvimento dos processos psicológicos superiors / L. S. Vigotski ; organizadores Michael Cole... [et al.] ; tradução José Cipolla Neto, Luís Silveira Menna Barreto, Solange Castro Afeche. $-7^{\mathrm{a}}$ ed. - São Paulo : Martins Fontes, 2007. 
WENGER, Etienne. Communities of practice - Learning, meaning, and identity. Cambridge University Press, 2008 - 18 a edição.

XAVIER, Rosely P. O que os professores de línguas estrangeiras necessitam saber sobre o ensino baseado em tarefas? In: KLEBER, A. S.; DANIEL, F. G.; KANEKOMARQUES, S. M.; SALOMÃO, A.C.B.. (Org.). A Formação de Professores de Línguas: Novos Olhares. 1 ed. Campinas: Pontes Editores, 2011, v. 1, p. 147-172. 


\section{ANEXO 1}

Olá caros alunos,

estamos desenvolvendo uma pesquisa para uma disciplina do curso de Mestrado que fazemos e gostaríamos que vocês nos ajudassem respondendo o questionário em anexo. Todas as informações serão sigilosas, ou seja, não será revelada a identidade do aluno. Pedimos que vocês respondam com a máxima sinceridade, assim teremos como avaliar melhor nossas propostas didáticas.

Desde já agradecemos,

Professoras Jovania e Ester

1. Quais as diferenças entre aprender português no seu país e no Brasil?

2. Você considera trabalhar com um colega uma atividade agradável?

3. Você considera trabalhar com um colega uma atividade produtiva?

4. Você teve a experiência de participar de um grupo, em que os alunos de origens, idiomas e culturas diversas. Na sua opinião, essas diferenças ajudaram ou dificultaram o trabalho em grupo ou em dupla?

5. Como você se sentiu desenvolvendo uma atividade em sala com um colega que tinha um nível linguístico acima do seu?

6. Como você se sentiu desenvolvendo uma atividade em sala com um colega que tinha um nível linguístico abaixo do seu?

7. Que tipo de atividades são desenvolvidas melhor com a companhia de um colega?

8. Em que medida as atividades colaborativas em sala de aula (que você tinha que fazer com um colega) ajudaram você a desenvolver seu nível linguístico?

\section{Aluno 1}

1. Quais as diferenças entre aprender português no seu país e no Brasil? Não posso responder porque nunca tinha aprendido português no meu país.

2. Você considera trabalhar com um colega uma atividade agradável?

Só se eu tiver que. Acho que todos nós esperamos da escola mais do que falar com outro estudante. Seria ótimo se tivéssemos mais gramática e aprender mais vocabulário. Eu acho que a gramática é fundamento, vocabulário é algo como paredes da casa - escola precisa ajudar a construí-los. É telhado da casa - prática falar com as pessoas - o aluno pode construir por si mesmo, praticando em seu tempo livre. 
3. Você considera trabalhar com um colega uma atividade produtiva?

4. Você teve a experiência de participar de um grupo, em que os alunos de origens, idiomas e culturas diversas. Na sua opinião, essas diferenças ajudaram ou dificultaram o trabalho em grupo ou em dupla?

Eu gosto de atividades quando um professor primeiro dá para nós lista de vocabulário e frases sobre um assunto e 2 alunos ou grupo tem que discutem sobre este assunto utilizando essas palavras e frases. No tempo de discussão o professor ouve e corrige. Sem a correção do professor não tem nenhum senso de trabalhar em grupo.

5. Como você se sentiu desenvolvendo uma atividade em sala com um colega que tinha um nível linguístico acima do seu?

Eu gosto de me desafiar, eu acho que me estimular para fazer melhor.

6. Como você se sentiu desenvolvendo uma atividade em sala com um colega que tinha um nível linguístico abaixo do seu?

Eu acho que sempre eu fui a pior, por isso não posso responder.

7. Que tipo de atividades são desenvolvidas melhor com a companhia de um colega?

Já respondida em 4.

8. Em que medida as atividades colaborativas em sala de aula (que você

tinha que fazer com um colega) ajudaram você a desenvolver seu nível linguístico?

Quando toda a classe fez exercícios gramaticais em voz alta.

P.S. Tudo aqui não tem nenhum propósito de ofender, é apenas sugestões construtivas para ajudar. Obrigada.

\section{Aluno 2}

1. Quais as diferenças entre aprender português no seu país e no Brasil?

The main difference is that the rest of the students do not speak my language and so I am forced to communicate with them in Portuguese. This is obviously a good thing.

2. Você considera trabalhar com um colega uma atividade agradável? Muito agradável!

3. Você considera trabalhar com um colega uma atividade produtiva?

Logico que sim.

4. Você teve a experiência de participar de um grupo, em que os alunos de origens, idiomas e culturas diversas. Na sua opinião, essas diferenças ajudaram ou dificultaram o trabalho em grupo ou em dupla?

Ajudaram. Por duas razoes: aquela da resposta \#1 e o fato que origens, idiomas e culturas diversas fizeram as aulas muito divertidas. 
5. Como você se sentiu desenvolvendo uma atividade em sala com um colega que tinha um nível linguístico acima do seu?

Impressed by how people that speak such different languages than Portuguese can speak it better than I (Spanish speaker). That incentivized me to work harder.

6. Como você se sentiu desenvolvendo uma atividade em sala com um colega que tinha um nível linguístico abaixo do seu?

Tudo bem comigo.

7. Que tipo de atividades são desenvolvidas melhor com a companhia de um colega? All of them.

8. Em que medida as atividades colaborativas em sala de aula (que você tinha que fazer com um colega) ajudaram você a desenvolver seu nível linguístico?

Pensar rápido.

\section{Aluno 3}

1. Quais as diferenças entre aprender português no seu país e no Brasil?

As diferenças são que você pode praticar dia adia porque está convivendo com o idioma sempre, além de que você aprende o jeito em que as pessoas brasileiras falam e não só o jeito de escrever.

2. Você considera trabalhar com um colega uma atividade agradável?

Acho agradável mas depois precisa ter uma dinâmica com o grupo inteiro. Quando eu mais gosto de trabalhar com alguém é quando depois tem uma discussão geral e não só uma exposição do tema, as vezes fica sem graça ter que escutar todos os colegas sem a oportunidade de falar.

3. Você considera trabalhar com um colega uma atividade produtiva?

Sim, acho que sim, sempre que as duas pessoas trabalhem, assim você pode praticar o idioma melhor e não ficar só escutando. Acho interessante quando

todos compartilham suas ideias porque assim você conhece e aprende mais dos colegas.

4. Você teve a experiência de participar de um grupo, em que os alunos de origens, idiomas e culturas diversas. Na sua opinião, essas diferenças ajudaram ou dificultaram o trabalho em grupo ou em dupla?

Sim e acho que ajuda muito porque você é forçado a praticar só o português, além de que sempre es bom aprender acerca de outra culturas. Outra coisa que achei boa foi que as vezes o idioma dos outros colegas tem outras dificuldades e assim suas duvidas são outras o que e bom porque você termina aprendendo alguma coisa nova ou reafirmando o que você já achava certo.

5. Como você se sentiu desenvolvendo uma atividade em sala com um colega que tinha um nível linguístico acima do seu?

Ao principio pode ser desconfortável, mas se você aproveita pode aprender de alguém que sabe um poco mais. 
6. Como você se sentiu desenvolvendo uma atividade em sala com um colega que tinha um nível linguístico abaixo do seu?

Também pode ser um pouco desconfortável, mas é bom porque assim você tenta a ajuda a seu colega para que entenda melhor, e assim você tem que procurar o melhor jeito de falar.

7. Que tipo de atividades são desenvolvidas melhor com a companhia de um colega?

Quando tem que debater ou discutir de um tema, assim a conversa ou o trabalho se torna mais dinâmico porque os dois tem que dar sua opinião.

8. Em que medida as atividades colaborativas em sala de aula (que você tinha que fazer com um colega) ajudaram você a desenvolver seu nível linguístico?

Acho que ajudou para praticar a fala, isso é bom para começar mas depois tem que ter mais conversas onde mais pessoas escutem a quem está falando.

\section{Aluno 4}

1. Quais as diferenças entre aprender português no seu país e no Brasil?

Eu não fiz nenhum estudo organizado português na Noruega ou nos Estados Unidos, enquanto eu morava lá. Comecei meu estudo português com Básico 1 no Celin. Português brasileiro não é comum na Noruega. (Meu amigo estudou português de Portugal na Noruega.)

2. Você considera trabalhar com um colega uma atividade agradável?

3. Você considera trabalhar com um colega uma atividade produtiva?

Eu não tenho certeza se entendi a pergunta 2 e 3, mas eu suponho que eles estão referindose a formas de aprender e usar português, tanto como parte da aula de língua e na vida outeside aulas de língua. Agora eu uso português durante os e quando eu falo com meus amigos brasileiros. Interação com outras pessoas em atividades sociais normais, é uma parte importante do aprendizado. Uma atividade planejada, onde dois alunos de Portugues para estrangeiros trabalham conjunto e interagem com os brasileiros também poderia ser uma forma de interação que vai ajudar o processo de aprendizagem. Acho que vou considerar trabalhar com um colega tanto uma atividade produtiva e uma atividade agradável.

4. Você teve a experiência de participar de um grupo, em que os alunos de origens, idiomas e culturas diversas. Na sua opinião, essas diferenças ajudaram ou dificultaram o trabalho em grupo ou em dupla?

Tenho experiência em trabalhar com coreano. Isso me ajudou muito quando aprender português. Eu sou obrigado a falar português com eles, tanto em sala de aula e quando eu encontrá-los fora das aulas, porque muitos deles não falam Inglês como a maioria das pessoas da Europa e Estados Unidos. Eu recomendo Celin sempre fazer duplas de um estudante coreano e um de outros países.

5. Como você se sentiu desenvolvendo uma atividade em sala com um colega que tinha um nível linguístico acima do seu? 
Eu acho que me ajudaria a aprender a língua com os alunos que conhecem a língua melhor do que eu.

6. Como você se sentiu desenvolvendo uma atividade em sala com um colega que tinha um nível linguístico abaixo do seu?

Acho que também me ajudaria, porque então eu preciso repetir o que já aprendi quando ajudo o outro estudante.

7. Que tipo de atividades são desenvolvidas melhor com a companhia de um colega? Pergunta difícil. Eu acho que uma atividade que é semelhante ao que o aluno vai experimentar na vida normal seria o melhor. Talvez teatro com muita interação verbal em um ambiente contemporâneo poderia ser na ideia.

8. Em que medida as atividades colaborativas em sala de aula (que você tinha que fazer com um colega) ajudaram você a desenvolver seu nível linguístico?

Senti que as entrevistas informais e brincadeiras na aula me ajudou.

\section{Aluno 5}

1. Quais as diferenças entre aprender português no seu país e no Brasil?

Aqui tem mais atividade de assistir e ouvir um vídeo e também tem mais tarefas para escrever textos.

2. Você considera trabalhar com um colega uma atividade agradável? Sim

3. Você considera trabalhar com um colega uma atividade produtiva?

Sim, mas às vezes achava não produtiva porque o assunto da conversação não tinha muito a falar.

4. Você teve a experiência de participar de um grupo, em que os alunos de origens, idiomas e culturas diversas. Na sua opinião, essas diferenças ajudaram ou dificultaram o trabalho em grupo ou em dupla?

As diferenças me ajudaram, mas para mim, na verdade quando conversei com um colega da França foi muito difícil (Sou coreana e acho que para coreanos é difícil entender a pronúncia de um francês.

5. Como você se sentiu desenvolvendo uma atividade em sala com um colega que tinha um nível linguístico acima do seu?

Me senti que me ajudou muito para aprender português e também deu-me o motivo para aprender mais.

6. Como você se sentiu desenvolvendo uma atividade em sala com um colega que tinha um nível linguístico abaixo do seu?

Me senti mais confortável e podia falar mais do que eu fiz uma atividade com um colega mais acima de mim. 
7. Que tipo de atividades são desenvolvidas melhor com a companhia de um colega? Ler uma notícia ou assistir um vídeo e depois explicar para um colega.

8. Em que medida as atividades colaborativas em sala de aula (que você tinha que fazer com um colega) ajudaram você a desenvolver seu nível linguístico?

Ler uma notícia ou assistir um vídeo e depois explicar sobre isso para um colega me ajudou muito.

\section{Aluno 6}

1. Quais as diferenças entre aprender português no seu país e no Brasil? Só uma aula eu tinha professora brasileira e nas outras aulas está usando por coreanos.

2. Você considera trabalhar com um colega uma atividade agradável?

3. Você considera trabalhar com um colega uma atividade produtiva?

4. Você teve a experiência de participar de um grupo, em que os alunos de origens, idiomas e culturas diversas. Na sua opinião, essas diferenças ajudaram ou dificultaram o trabalho em grupo ou em dupla?

Acho que essas diferenças podem ajudar.

5. Como você se sentiu desenvolvendo uma atividade em sala com um colega que tinha um nível linguístico acima do seu?

Me sentia ruim e estava pensando que treinar mais.

6. Como você se sentiu desenvolvendo uma atividade em sala com um colega que tinha um nível linguístico abaixo do seu?

Nada.

7. Que tipo de atividades são desenvolvidas melhor com a companhia de um colega? Acho que conversação.

8. Em que medida as atividades colaborativas em sala de aula (que você tinha que fazer com um colega) ajudaram você a desenvolver seu nível linguístico? Acho que cada vez mais to desenvolvendo.

\section{Aluno 7}

1. Quais as diferenças entre aprender português no seu país e no Brasil? Eu só aprendo português no Brasil.

2. Você considera trabalhar com um colega uma atividade agradável? Sim, eu gosto muito isso. 
3. Você considera trabalhar com um colega uma atividade produtiva? Acho que não faz diferença. Também eu gosto disso.

4. Você teve a experiência de participar de um grupo, em que os alunos de origens, idiomas e culturas diversas. Na sua opinião, essas diferenças ajudaram ou dificultaram o trabalho em grupo ou em dupla?

Eu gosto os dois porque gosto de aprender com os outros e também ajudar os outros.

5. Como você se sentiu desenvolvendo uma atividade em sala com um colega que tinha um nível linguístico acima do seu?

6. Como você se sentiu desenvolvendo uma atividade em sala com um colega que tinha um nível linguístico abaixo do seu?

7. Que tipo de atividades são desenvolvidas melhor com a companhia de um colega?

8. Em que medida as atividades colaborativas em sala de aula (que você tinha que fazer com um colega) ajudaram você a desenvolver seu nível linguístico?

\section{Aluno 8}

1. Quais as diferenças entre aprender português no seu país e no Brasil? Na Coreia tem mais aulas de gramática do que de conversação. Mas aqui no Brasil posso praticar mais a falar português.

2. Você considera trabalhar com um colega uma atividade agradável? Trabalhar com um colega me fez que eu participava mais.

3. Você considera trabalhar com um colega uma atividade produtiva? Eu gostava de trabalhar com um colega de outros países e eles me ajudavam.

4. Você teve a experiência de participar de um grupo, em que os alunos de origens, idiomas e culturas diversas. Na sua opinião, essas diferenças ajudaram ou dificultaram o trabalho em grupo ou em dupla?

5. Como você se sentiu desenvolvendo uma atividade em sala com um colega que tinha um nível linguístico acima do seu?

Às vezes eles me ajudavam com palavras que eu não sabia.

6. Como você se sentiu desenvolvendo uma atividade em sala com um colega que tinha um nível linguístico abaixo do seu?

Eu tentava dar informações que meu colega tinha dúvidas.

7. Que tipo de atividades são desenvolvidas melhor com a companhia de um colega?

Atividade de compartilhar cada opinião. 
8. Em que medida as atividades colaborativas em sala de aula (que você tinha que fazer com um colega) ajudaram você a desenvolver seu nível linguístico?

Mesmo número 7.

\section{Aluno 9}

1. Quais as diferenças entre aprender português no seu país e no Brasil? Na Coreia nós só estudamos com livros e gramáticas, mas aqui nós podemos encontrar pessoas de culturas diferentes e melhorar nossa habilidade de falar português.

2. Você considera trabalhar com um colega uma atividade agradável? Sim.

3. Você considera trabalhar com um colega uma atividade produtiva? Sim.

4. Você teve a experiência de participar de um grupo, em que os alunos de origens, idiomas e culturas diversas. Na sua opinião, essas diferenças ajudaram ou dificultaram o trabalho em grupo ou em dupla?

Foi bom porque nós já estamos acostumados com nossa cultura, com experiência de amigos diferentes eu pude entender e ter contato com estrangeiros.

5. Como você se sentiu desenvolvendo uma atividade em sala com um colega que tinha um nível linguístico acima do seu?

Senti ele me ensinando.

6. Como você se sentiu desenvolvendo uma atividade em sala com um colega que tinha um nível linguístico abaixo do seu?

Senti que ele estive ensinando.

7. Que tipo de atividades são desenvolvidas melhor com a companhia de um colega?

Entregando escritos, conversando com colegas.

8. Em que medida as atividades colaborativas em sala de aula (que você tinha que fazer com um colega) ajudaram você a desenvolver seu nível linguístico?

Entregando escritos, provas, apresentação.

\section{Aluno 10}

1. Quais as diferenças entre aprender português no seu país e no Brasil? Quando estudei na minha Universidade eles não me ensinaram todas as coisas certas. Aqui aprendi melhor o jeito de falar das pessoas.

2. Você considera trabalhar com um colega uma atividade agradável? Sim muito! Eu gosto de conhecer colegas. 
3. Você considera trabalhar com um colega uma atividade produtiva? Depende das pessoas.

4. Você teve a experiência de participar de um grupo, em que os alunos de origens, idiomas e culturas diversas. Na sua opinião, essas diferenças ajudaram ou dificultaram o trabalho em grupo ou em dupla?

Ajuda a tentar mais a falar em português e tentar a entender o outra cultura (maneira de pensar da pessoa).

5. Como você se sentiu desenvolvendo uma atividade em sala com um colega que tinha um nível linguístico acima do seu?

Me senti com mais motivação para aprender português.

6. Como você se sentiu desenvolvendo uma atividade em sala com um colega que tinha um nível linguístico abaixo do seu?

Me senti com vergonha a falar muito.

7. Que tipo de atividades são desenvolvidas melhor com a companhia de um colega?

Para entender textos, cumprir metas e para praticar falar sobre suas experiências.

8. Em que medida as atividades colaborativas em sala de aula (que você

tinha que fazer com um colega) ajudaram você a desenvolver seu nível linguístico?

Contando experiências, explicando nossas culturas, entender textos e áudios.

\section{Aluno 11}

1. Quais as diferenças entre aprender português no seu país e no Brasil?

Na Coreia aprendi só gramática e não fui satisfeito que conversar com pessoas em português.

2. Você considera trabalhar com um colega uma atividade agradável?

Sim, cozinhávamos as comidas coreanas.

3. Você considera trabalhar com um colega uma atividade produtiva?

Sim, conversávamos sobre a vida no Brasil.

4. Você teve a experiência de participar de um grupo, em que os alunos de origens, idiomas e culturas diversas. Na sua opinião, essas diferenças ajudaram ou dificultaram o trabalho em grupo ou em dupla?

Essas me ajudaram! Podia trocar as informações sobre países e podeia saber sobre várias culturas.

5. Como você se sentiu desenvolvendo uma atividade em sala com um colega que tinha um nível linguístico acima do seu?

No início não entendia ninguém e foi difícil para mim. Mas depois de 2 meses pude ouvir português e conversar com as professoras. Agora, tenho a confiança. 
6. Como você se sentiu desenvolvendo uma atividade em sala com um colega que tinha um nível linguístico abaixo do seu?

Acho que é ruim. Não posso me desenvolver.

7. Que tipo de atividades são desenvolvidas melhor com a companhia de um colega?

Tandem foi legal. Mas na verdade, tive só duas vezes com tandem, por isso queria me encontrar mais.

8. Em que medida as atividades colaborativas em sala de aula (que você tinha que fazer com um colega) ajudaram você a desenvolver seu nível linguístico?

Sim porque conversar é mais importante. Por isso, posso desenvolver o nível por atividades colaborativas.

\section{Aluno 12}

1. Quais as diferenças entre aprender português no seu país e no Brasil? Tem mais oportunidade de conversar e ouvir português. Posso aprender algumas expressões informais.

2. Você considera trabalhar com um colega uma atividade agradável?

Eu queria ter mais oportunidade de conversar, mas conversar com colegas que têm mesmo nível não é bom para desenvolver.

3. Você considera trabalhar com um colega uma atividade produtiva?

Na verdade eu não gosto de fazer atividades com outros. Mas, não tive problemas.

4. Você teve a experiência de participar de um grupo, em que os alunos de origens, idiomas e culturas diversas. Na sua opinião, essas diferenças ajudaram ou dificultaram o trabalho em grupo ou em dupla?

Eu quase sempre fiz atividade com coreanos, por isso não senti dificuldades.

5. Como você se sentiu desenvolvendo uma atividade em sala com um colega que tinha um nível linguístico acima do seu?

Pode me ajudar, por isso eu senti desenvolvimento.

6. Como você se sentiu desenvolvendo uma atividade em sala com um colega que tinha um nível linguístico abaixo do seu?

Não tem problema.

7. Que tipo de atividades são desenvolvidas melhor com a companhia de um colega?

Preparar apresentação.

8. Em que medida as atividades colaborativas em sala de aula (que você tinha que fazer com um colega) ajudaram você a desenvolver seu nível linguístico? 
Às vezes me ajudavam a desenvolver meu nível porque podia trocar algumas informações em português e etc.

\section{Aluno 13}

9. Quais as diferenças entre aprender português no seu país e no Brasil? Na Coreia aprendi só gramática e não fui satisfeito que conversar com pessoas em português.

10. Você considera trabalhar com um colega uma atividade agradável? Sim, cozinhávamos as comidas coreanas.

11. Você considera trabalhar com um colega uma atividade produtiva? Sim, conversávamos sobre a vida no Brasil.

12. Você teve a experiência de participar de um grupo, em que os alunos de origens, idiomas e culturas diversas. Na sua opinião, essas diferenças ajudaram ou dificultaram o trabalho em grupo ou em dupla?

Essas me ajudaram! Podia trocar as informações sobre países e podeia saber sobre várias culturas.

13. Como você se sentiu desenvolvendo uma atividade em sala com um colega que tinha um nível linguístico acima do seu?

No início não entendia ninguém e foi difícil para mim. Mas depois de 2 meses pude ouvir português e conversar com as professoras. Agora, tenho a confiança.

14. Como você se sentiu desenvolvendo uma atividade em sala com um colega que tinha um nível linguístico abaixo do seu?

Acho que é ruim. Não posso me desenvolver.

15. Que tipo de atividades são desenvolvidas melhor com a companhia de um colega?

Tandem foi legal. Mas na verdade, tive só duas vezes com tandem, por isso queria me encontrar mais.

16. Em que medida as atividades colaborativas em sala de aula (que você tinha que fazer com um colega) ajudaram você a desenvolver seu nível linguístico?

Sim porque conversar é mais importante. Por isso, posso desenvolver o nível por atividades colaborativas.

\section{Aluno 14}

1. Quais as diferenças entre aprender português no seu país e no Brasil? No Brasil às vezes, não posso entender exatamente porque o professor não explica em coreano sobre a gramática.

2. Você considera trabalhar com um colega uma atividade agradável? 
Ainda não considero que isso é agradável.

3. Você considera trabalhar com um colega uma atividade produtiva?

Entender cultura estrangeira é uma atividade produtiva.

4. Você teve a experiência de participar de um grupo, em que os alunos de origens, idiomas e culturas diversas. Na sua opinião, essas diferenças ajudaram ou dificultaram o trabalho em grupo ou em dupla?

Foi bom, na Coréia não sabia o pensamento das pessoas estrangeiras. Pelo curso, consigo entender isso.

5. Como você se sentiu desenvolvendo uma atividade em sala com um colega que tinha um nível linguístico acima do seu?

Sim, principalmente agora sinto desenvolvido uma atividade.

6. Como você se sentiu desenvolvendo uma atividade em sala com um colega que tinha um nível linguístico abaixo do seu?

Também senti.

7. Que tipo de atividades são desenvolvidas melhor com a companhia de um colega?

Apresentação para os colegas é melhor porque tenho que entender tudo que eu vou fazer e por isso, precisa fazer mais esforço.

8. Em que medida as atividades colaborativas em sala de aula (que você tinha que fazer com um colega) ajudaram você a desenvolver seu nível linguístico?

Apresentação e escrever um ensaio e corrigido pelo professor.

\section{Aluno 15}

1. Quais as diferenças entre aprender português no seu país e no Brasil? É melhor aprender no Brasil porque posso aprender palavras úteis.

2. Você considera trabalhar com um colega uma atividade agradável? Sim!

3. Você considera trabalhar com um colega uma atividade produtiva? Sim!

4. Você teve a experiência de participar de um grupo, em que os alunos de origens, idiomas e culturas diversas. Na sua opinião, essas diferenças ajudaram ou dificultaram o trabalho em grupo ou em dupla?

Claro! Tem muitos coreanos no CELIN e é difícil para comunicar com estrangeiros.

Encontrar com eles é uma experiência boa.

5. Como você se sentiu desenvolvendo uma atividade em sala com um colega que tinha um nível linguístico acima do seu? 
No inicia foi difícil para falar e apresentar em frente deles. Mas depois... podia entender e ouvir bem.

6. Como você se sentiu desenvolvendo uma atividade em sala com um colega que tinha um nível linguístico abaixo do seu?

Era difícil também porque eles gostavam muito tempo desnecessário. Mas, era bom para aprender as coisas básicas.

7. Que tipo de atividades são desenvolvidas melhor com a companhia de um colega? Jogar.

8. Em que medida as atividades colaborativas em sala de aula (que você tinha que fazer com um colega) ajudaram você a desenvolver seu nível linguístico?

Escrever e corrigir. E... jogar com companhia.

\section{Aluno 16}

1. Quais as diferenças entre aprender português no seu país e no Brasil? No Brasil tem que fazer mais conversação. No Japão pode aprender mais gentil.

2. Você considera trabalhar com um colega uma atividade agradável? Sim.

3. Você considera trabalhar com um colega uma atividade produtiva? Sim.

4. Você teve a experiência de participar de um grupo, em que os alunos de origens, idiomas e culturas diversas. Na sua opinião, essas diferenças ajudaram ou dificultaram o trabalho em grupo ou em dupla?

Não tem diferença. Interessante.

5. Como você se sentiu desenvolvendo uma atividade em sala com um colega que tinha um nível linguístico acima do seu?

6. Como você se sentiu desenvolvendo uma atividade em sala com um colega que tinha um nível linguístico abaixo do seu?

7. Que tipo de atividades são desenvolvidas melhor com a companhia de um colega?

8. Em que medida as atividades colaborativas em sala de aula (que você tinha que fazer com um colega) ajudaram você a desenvolver seu nível linguístico? 


\section{Aluno 17}

1. Quais as diferenças entre aprender português no seu país e no Brasil? Aprender no Brasil é mais educativo porque a professora é brasileira e fala português. Os alunos são estrangeiros, então tenho que falar e perguntar usando português.

2. Você considera trabalhar com um colega uma atividade agradável? Sim, porque eu posso me divertir com um colega.

3. Você considera trabalhar com um colega uma atividade produtiva? Sim, porque sempre preciso falar português na aula.

4. Você teve a experiência de participar de um grupo, em que os alunos de origens, idiomas e culturas diversas. Na sua opinião, essas diferenças ajudaram ou dificultaram o trabalho em grupo ou em dupla?

O trabalho em dupla ajuda mais comunicar usando português e conseguir falar sobre mais coisas. O trabalho em grupo é mais difícil de entender porque eu não consigo perguntar muitas vezes.

5. Como você se sentiu desenvolvendo uma atividade em sala com um colega que tinha um nível linguístico acima do seu?

Eu senti que o nível é mais acima de mim.

6. Como você se sentiu desenvolvendo uma atividade em sala com um colega que tinha um nível linguístico abaixo do seu?

7. Que tipo de atividades são desenvolvidas melhor com a companhia de um colega? Jogo de questões.

8. Em que medida as atividades colaborativas em sala de aula (que você tinha que fazer com um colega) ajudaram você a desenvolver seu nível linguístico?

\section{Aluno 18}

1. Quais as diferenças entre aprender português no seu país e no Brasil? Aprender português aqui é mais fácil. O aluno aprende mais rapidamente.

2. Você considera trabalhar com um colega uma atividade agradável? Às vezes sim, às vezes não.

3. Você considera trabalhar com um colega uma atividade produtiva? Sim.

4. Você teve a experiência de participar de um grupo, em que os alunos de origens, idiomas e culturas diversas. Na sua opinião, essas diferenças ajudaram ou dificultaram o trabalho em grupo ou em dupla?

Não, é muito lega, mas às vezes tem um grupo que evolui mais do que os outros. 
5. Como você se sentiu desenvolvendo uma atividade em sala com um colega que tinha um nível linguístico acima do seu?

Posso aproveitar dessa situação para aprender ainda mais.

6. Como você se sentiu desenvolvendo uma atividade em sala com um colega que tinha um nível linguístico abaixo do seu?

7. Que tipo de atividades são desenvolvidas melhor com a companhia de um colega? Uma conversa sobre as coisas do dia a dia.

8. Em que medida as atividades colaborativas em sala de aula (que você tinha que fazer com um colega) ajudaram você a desenvolver seu nível linguístico?

\section{Aluno 19}

1. Quais as diferenças entre aprender português no seu país e no Brasil? No meu país tem só um curso de língua portuguesa e aquele é de Portugal.

2. Você considera trabalhar com um colega uma atividade agradável?

3. Você considera trabalhar com um colega uma atividade produtiva?

4. Você teve a experiência de participar de um grupo, em que os alunos de origens, idiomas e culturas diversas. Na sua opinião, essas diferenças ajudaram ou dificultaram o trabalho em grupo ou em dupla?

5. Como você se sentiu desenvolvendo uma atividade em sala com um colega que tinha um nível linguístico acima do seu?

Acho que é legal, porque ele pode me ajudar em alguma coisa que eu não sabia.

6. Como você se sentiu desenvolvendo uma atividade em sala com um colega que tinha um nível linguístico abaixo do seu?

7. Que tipo de atividades são desenvolvidas melhor com a companhia de um colega?

Um jogo ou trabalho em grupo.

8. Em que medida as atividades colaborativas em sala de aula (que você tinha que fazer com um colega) ajudaram você a desenvolver seu nível linguístico?

\section{Aluno 20}

17. Quais as diferenças entre aprender português no seu país e no Brasil?

Na Coreia aprendi só gramática e não fui satisfeito que conversar com pessoas em português. 
18. Você considera trabalhar com um colega uma atividade agradável? Sim, cozinhávamos as comidas coreanas.

19. Você considera trabalhar com um colega uma atividade produtiva? Sim, conversávamos sobre a vida no Brasil.

20. Você teve a experiência de participar de um grupo, em que os alunos de origens, idiomas e culturas diversas. Na sua opinião, essas diferenças ajudaram ou dificultaram o trabalho em grupo ou em dupla?

Essas me ajudaram! Podia trocar as informações sobre países e podeia saber sobre várias culturas.

21. Como você se sentiu desenvolvendo uma atividade em sala com um colega que tinha um nível linguístico acima do seu?

No início não entendia ninguém e foi difícil para mim. Mas depois de 2 meses pude ouvir português e conversar com as professoras. Agora, tenho a confiança.

22. Como você se sentiu desenvolvendo uma atividade em sala com um colega que tinha um nível linguístico abaixo do seu?

Acho que é ruim. Não posso me desenvolver.

23. Que tipo de atividades são desenvolvidas melhor com a companhia de um colega?

Tandem foi legal. Mas na verdade, tive só duas vezes com tandem, por isso queria me encontrar mais.

24. Em que medida as atividades colaborativas em sala de aula (que você tinha que fazer com um colega) ajudaram você a desenvolver seu nível linguístico?

Sim porque conversar é mais importante. Por isso, posso desenvolver o nível por atividades colaborativas.

\section{Aluno 21}

1. Quais as diferenças entre aprender português no seu país e no Brasil? É bem melhor aqui porque estou mergulhado em português.

2. Você considera trabalhar com um colega uma atividade agradável? É muito agradável.

3. Você considera trabalhar com um colega uma atividade produtiva? Sim, considero muito produtiva. É muito bom falar com os colegas.

4. Você teve a experiência de participar de um grupo, em que os alunos de origens, idiomas e culturas diversas. Na sua opinião, essas diferenças ajudaram ou dificultaram o trabalho em grupo ou em dupla?

Eu acho que é melhor em dupla com este nível. Mas eu acho que em grupo é melhor nos níveis altos. 
5. Como você se sentiu desenvolvendo uma atividade em sala com um colega que tinha um nível linguístico acima do seu?

Acho que é bom porque eu posso aprender mais.

6. Como você se sentiu desenvolvendo uma atividade em sala com um colega que tinha um nível linguístico abaixo do seu?

É bom porque eu gosto de ensinar, mas não é bom para mim porque não vou aprender com uma pessoa que tinha um nível abaixo do meu.

7. Que tipo de atividades são desenvolvidas melhor com a companhia de um colega?

Discutir os textos.

8. Em que medida as atividades colaborativas em sala de aula (que você tinha que fazer com um colega) ajudaram você a desenvolver seu nível linguístico?

Textos por causa de vocabulário.

\section{Aluno 22}

1. Quais as diferenças entre aprender português no seu país e no Brasil? No Brasil a gente tem que falar todo dia e com as pessoas na vida real.

2. Você considera trabalhar com um colega uma atividade agradável? Sim, podemos nos conhecer um pouco melhor.

3. Você considera trabalhar com um colega uma atividade produtiva? Sim, podemos colocar

4. Você teve a experiência de participar de um grupo, em que os alunos de origens, idiomas e culturas diversas. Na sua opinião, essas diferenças ajudaram ou dificultaram o trabalho em grupo ou em dupla?

Dificultaram por causa da língua, mas ajudaram também para falar português.

5. Como você se sentiu desenvolvendo uma atividade em sala com um colega que tinha um nível linguístico acima do seu?

A pessoa pode explicar as palavras que eu não entendo.

6. Como você se sentiu desenvolvendo uma atividade em sala com um colega que tinha um nível linguístico abaixo do seu?

Eu posso ajudar o colega que tem mais dificuldade.

7. Que tipo de atividades são desenvolvidas melhor com a companhia de um colega?

Bate-papo sobre um exercício, apresentação, ...

8. Em que medida as atividades colaborativas em sala de aula (que você

tinha que fazer com um colega) ajudaram você a desenvolver seu nível linguístico?

As atividades ajudaram aprender novas palavras e esforçar para falar português ao início (quando era muito mais difícil). 


\section{Aluno 23}

1. Quais as diferenças entre aprender português no seu país e no Brasil?

Se eu aprendesse português no meu país não falarei o mínimo que eu estou falando agora, porque lá tem menos de 5\% da população de fala português. Então se aprendesse português no meu país não iria praticá-lo muito, mas aqui no Brasil sou obrigado de falar português.

2. Você considera trabalhar com um colega uma atividade agradável?

Sim é uma atividade agradável por causa da complementação que existe dentro da sala quando fazemos exercícios.

3. Você considera trabalhar com um colega uma atividade produtiva?

Sim, é uma atividade produtiva porque juntos vamos fazer um bom trabalho. Se alguém não conhecesse algo o colega poderia ajudar para atingir o bom resultado.

4. Você teve a experiência de participar de um grupo, em que os alunos de origens, idiomas e culturas diversas. Na sua opinião, essas diferenças ajudaram ou dificultaram o trabalho em grupo ou em dupla?

No início parece sempre difícil de trabalhar com uma pessoa que tem muitas diferenças, sobretudo a diferença das línguas. Imagine que você esteja em frente duma pessoa com quem você deve trabalhar juntos, mas numa língua que vocês dois não falam bem; cada um terá medo de falar errado. Mas com tempo tudo fica fácil, porque já se acostumaram de falar errado e de ser corrigido pela professora. E nesse momento essa diferença ajudará porque será obrigado de falar a língua que vocês estão aprendendo.

5. Como você se sentiu desenvolvendo uma atividade em sala com um colega que tinha um nível linguístico acima do seu?

Vou aproveitar para perguntá-lo sobre todas as dúvidas para atingir meu nível de conhecimento.

6. Como você se sentiu desenvolvendo uma atividade em sala com um colega que tinha um nível linguístico abaixo do seu?

Vou ajudá-lo se ele quiser e vou também aproveitar de ouvi-lo, talvez ele saiba algumas palavras ou expressões que eu não conheço (sei).

7. Que tipo de atividades são desenvolvidas melhor com a companhia de um colega? Para mim é a compreensão de textos; a leitura também e a interpretação de vídeos e áudios.

8. Em que medida as atividades colaborativas em sala de aula (que você tinha que fazer com um colega) ajudaram você a desenvolver seu nível linguístico?

As atividades colaborativas em sala de aula me ajudaram a desenvolver meu nível lingüístico por causa da ajuda dos meus colegas e do sentimento de atingir sucesso nesse dia de aula. 


\section{Aluno 24}

1. Quais as diferenças entre aprender português no seu país e no Brasil? Eu não aprendi português no meu país, mas eu acho que aqui a diferença é que a gente está em contato direito com a língua portuguesa.

2. Você considera trabalhar com um colega uma atividade agradável? Trabalhar com um colega é uma atividade agradável porque a gente tem a possibilidade de fazer uma troca de conhecimento e de cultura.

3. Você considera trabalhar com um colega uma atividade produtiva? Sim, porque isso facilita juntos o conhecimento e de cultura.

4. Você teve a experiência de participar de um grupo, em que os alunos de origens, idiomas e culturas diversas. Na sua opinião, essas diferenças ajudaram ou dificultaram o trabalho em grupo ou em dupla?

Na minha opinião essas diferenças ajudaram e dificultaram o trabalho em grupo, pois cada um dos alunos tem uma ideia diferente e assim eles farão um trabalho complexo mas a diversidade de origens, idiomas e culturas não facilitarão a comunicação.

5. Como você se sentiu desenvolvendo uma atividade em sala com um colega que tinha um nível linguístico acima do seu?

Com um colega com um nível acima do meu eu me senti muito inferior como se eu não estou fazendo progresso na aprendizagem.

6. Como você se sentiu desenvolvendo uma atividade em sala com um colega que tinha um nível linguístico abaixo do seu?

Eu me senti feliz, fluente como se eu estou (estivesse) melhorando.

7. Que tipo de atividades são desenvolvidas melhor com a companhia de um colega?

Com a companhia de um colega as atividades de tipo debates são desenvolvidas melhor. Assim cada um dá sua opinião.

8. Em que medida as atividades colaborativas em sala de aula (que você tinha que fazer com um colega) ajudaram você a desenvolver seu nível linguístico?

As atividades colaborativas em sala de aula me ajudaram a desenvolver me nível, pois assim eu posso entender como ele pensa sobre o assunto que estamos estudando.

\section{Aluno 25}

1. Quais as diferenças entre aprender português no seu país e no Brasil? Não estudei português no meu país antes de chegar aqui no Brasil.

2. Você considera trabalhar com um colega uma atividade agradável? Sim, considero isso muito agradável.

3. Você considera trabalhar com um colega uma atividade produtiva? 
Sim.

4. Você teve a experiência de participar de um grupo, em que os alunos de origens, idiomas e culturas diversas. Na sua opinião, essas diferenças ajudaram ou dificultaram o trabalho em grupo ou em dupla?

Sim, acho que essas diferenças ajudaram o trabalho em grupo ou em dupla porque essas diferenças fizeram que tudo mundo percebe as coisas de jeito de si mesmo e isso pode ajudar outro a entender o que não entende no seu jeito.

5. Como você se sentiu desenvolvendo uma atividade em sala com um colega que tinha um nível linguístico acima do seu?

Eu sinto isso muito interessante porque isso me ajuda a trabalhar mais e a desenvolver todo o brilho que tem em mim mesmo.

6. Como você se sentiu desenvolvendo uma atividade em sala com um colega que tinha um nível linguístico abaixo do seu?

Eu sinto isso normal.

7. Que tipo de atividades são desenvolvidas melhor com a companhia de um colega?

Compreensão de vídeos e áudios, porque esse diferente jeito de perceber as coisas ajuda muito em aprendizagem.

8. Em que medida as atividades colaborativas em sala de aula (que você tinha que fazer com um colega) ajudaram você a desenvolver seu nível linguístico?

Essas atividades me ajudaram a perceber meu sucesso e meu fracasso. 